\title{
The effect of varying levels of high- and low-tannin faba bean (Vicia faba L.) seeds on gastrointestinal function and growth performance in turkeys
}

\author{
M. Przywitowski', D. Mikulski ${ }^{1,3}$, J. Jankowski', J. Juśkiewicz², M. Mikulska' and Z. Zduńczyk² \\ ${ }^{1}$ University of Warmia and Mazury in Olsztyn, Department of Poultry Science \\ Oczapowskiego 5, 10-718 Olsztyn, Poland \\ ${ }^{2}$ Institute of Animal Reproduction and Food Research, Polish Academy of Sciences \\ Tuwima 10, 10-748 Olsztyn, Poland
}

KEY WORDS: turkeys, performance, digestive tract, faba beans, seeds, tannins

Received: 23 February 2017

Revised: 8 June 2017

Accepted: 1 August 2017
${ }^{3}$ Corresponding author:

e-mail: darekm@uwm.edu.pl

\begin{abstract}
A two-factor experiment was conducted to evaluate the effect of varying dietary levels $(10,20$ and $30 \%$ ) of faba bean (FB; Vicia faba L.) seeds with high- and low-tannin content (HT and LT, respectively) on the gastrointestinal function and performance of turkeys during the last 6 weeks of rearing. In the control group $\left(\mathrm{FB}_{0}\right)$, birds were fed maize-soyabean meal-based diets. In comparison with HT FB seeds, in LT seeds lower content of condensed tannins ( 0.78 vs $0.08 \% \mathrm{DM})$ was determined. Different dietary inclusion levels of HT and LT FB had no influence on feed intake or viscosity and pH of small intestinal digesta, and the $\mathrm{pH}$ of caecal digesta as compared with $\mathrm{FB}_{0}$. In comparison with $\mathrm{HT} F B$, LT seeds increased ammonia concentrations, decreased $\mathrm{pH}$ and reduced activity of microbial a-glucosidase in the caecal digesta. All diets containing FB stimulated the activity of $\beta$-glucuronidase in comparison with diet $\mathrm{FB}_{0}$. In turkeys fed $\mathrm{LT}$ seeds the production of short-chain fatty acids (SCFAs) was higher than in birds fed HT FB. Body weight gains of turkeys were comparable in all groups, however feed conversion ratio was lower in groups fed LT than HT FB seeds. So, FB enhanced fermentation processes in the gastrointestinal tract of turkeys, but had no influence on their performance. Both LT and HT FB seeds can be included in finisher turkey diets (up to $30 \%$ ) as an effective substitute for soyabean meal. FB with lower tannin content improved selected parameters of gastrointestinal function, including increased SCFA production in the caeca and so improved feed efficiency.
\end{abstract}

\section{Introduction}

The inclusion of faba bean (FB; Vicia faba L.) in diets for monogastric animals was investigated in numerous experiments performed in the last decade of the $20^{\text {th }}$ century (e.g., Van Der Poel et al., 1992; Smulikowska and Chibowska, 1993; Frejnagel et al., 1997). Fluctuations in the production volume and price of soyabean meal (SBM) has stirred interest in legumes (Jezierny et al., 2010) that can be used to improve soil fertility in agricultural ecosystems and provide natural protection against pests (Cazzato et al., 2012). In organic livestock production systems, the seeds of locally grown legume crops are a viable alternative to SBM with a high risk of GMO contamination (Tufarelli and Laudadio, 2015). 
One of the factors responsible for the limited suitability of FB seeds in intensive poultry feeding is their low protein content, usually not exceeding 30\% dry matter (DM) (Duc et al., 1999). The replacement of protein-richer SBM with FB seeds leads to a considerable increase in the total content of high-protein components in poultry diets (Vilariño et al., 2009; Nalle et al., 2010; Laudadio et al., 2011). Another factor reducing the feed value of seeds of colouredflower FB varieties is their high content of condensed polyphenols (tannins), ranging from 5 to $10 \mathrm{~g} \cdot \mathrm{kg}^{-1}$ DM (Duc et al., 1999). Many experiments have demonstrated that high-tannin FB seeds adversely affect feed intake (Iji et al., 2004) and decrease protein and energy utilization (Vilariño et al., 2009).

Tannins are present mostly in FB seed coats (Zduńczyk et al., 2003; Vilariño et al., 2009). Numerous studies have revealed a negative effect of tannins on feed intake, in particular on total protein digestibility and dietary energy utilization. Attempts have been made to remove the coats of seeds (dehulling) of conventional coloured-flower FB varieties in order to decrease the tannin content in FB-based diets (Smulikowska and Chibowska, 1993; Frejnagel et al., 1997), but the results were unsatisfactory. Another option is selective breeding of high-yielding white-flowering low-tannin FB varieties (Van der Poel et al., 1992).

The results of experiments investigating the use of seeds of white-flowering and coloured-flower FB varieties in rat and pig diets were comparable (Van der Poel et al., 1992; Frejnagel et al., 1997). In recent years, the seeds of new zero-tannin FB varieties have been successfully used in diets for growing-finishing pigs (Zijlstra et al., 2008) and broiler chickens (Vilariño et al., 2009; Nalle et al., 2010). The above findings suggest that FB seeds can also be fed to turkeys. The efficacy of FB in turkey nutrition has to be evaluated independently because turkeys are characterized by a longer fattening period and higher feed intake than broiler chickens.

Therefore, the aim of this study was to determine the gastrointestinal response of turkeys to varying dietary levels of high- and low-tannin FB seeds and their influence on the growth performance of birds in the last stage of rearing (6 weeks before slaughter).

\section{Material and methods}

All procedures were approved by the Local Ethics Committee of University of Warmia and Mazury, Olsztyn (Poland).

\section{Faba bean seeds}

Certified FB (Vicia faba L.) seeds with lowtannin (LT) content (var. Amulet) and high-tannin (HT) content (var. Bobas) were used in this experiment. FB varieties Amulet and Bobas were registered in 2008 and 2002, respectively (COBORU, 2011), and were harvested in 2013. The seeds were obtained from the Plant Breeding Station in Strzelce, Wielkopolska Voivodship (Poland).

\section{Animals and diets}

In total 1470 male 12-week old Hybrid Converter turkeys, with an average body weight (BW) of $10.54 \pm 0.19 \mathrm{~kg}$, were randomly divided into $7 \mathrm{ex}-$ perimental groups (210 turkeys in each) and placed in 7 replicate pens ( 30 birds per pen) on litter (wood shavings). Room temperature was $15 \pm 1{ }^{\circ} \mathrm{C}$ and the $18 \mathrm{~h}$ light $/ 6 \mathrm{~h}$ dark cycle was maintained throughout the study. The trial lasted 6 weeks, from 13 to 18 week of age. From hatching to week 12 all birds were fed commercial pelleted diet that met the NRC (1994) nutrient requirements of growing turkeys. During the experimental period (from 13 to 18 week of age), the birds received 7 finisher diets: $\mathrm{FB}_{0}$ - without $\mathrm{FB}$ seeds, $\mathrm{HT}_{10}$ - with $10 \%$ content of HT FB seeds, $\mathrm{HT}_{20}$ - with $20 \%$ of HT FB seeds, $\mathrm{HT}_{30}$ - with $30 \%$ of HT FB seeds, $\mathrm{LT}_{10}$ - with $10 \%$ of LT FB seeds, $\mathrm{LT}_{20}-$ with $20 \%$ of LT FB seeds, LT $_{30}$ - with $30 \%$ of LT FB seeds. Thus, the experiment consisted of 7 treatments including a control diet without FB seeds, and 6 additional diets forming a $2 \times 3$ factorial design with 2 varieties of $\mathrm{FB}$ (HT and LT) and 3 levels of FB inclusion $(10,20$ and $30 \%)$. All experimental diets were formulated to meet the nutrient requirements for turkeys as recommended by Hybrid Turkey (2013). Diets were isonitrogenous and isoenergetic (Table 1) and fed as $3.5 \mathrm{~mm}$ pellets (prepared by the Agrocentrum feed mill in Kaleczyn, Poland). The contents of lysine, methionine with cysteine, threonine, minerals (including calcium and available phosphorus) and vitamins in all diets were similar. Throughout the experiment, animals had ad libitum access to feed and water.

\section{Sample collection}

Body weight (BW), body weight gain (BWG) and feed consumption were recorded and calculated on a pen basis. Daily feed intake (DFI) per bird was calculated on a pen total feed consumption and days in the period. Feed conversion ratio (FCR) for the experimental period was calculated based on BWG and feed consumption. Mortality was recorded every day; the weights of dead birds were used to adjust average BWG, DFI and FCR. 
Table 1. Composition and nutrient content of experimental diets, $\%$, as-fed basis

\begin{tabular}{|c|c|c|c|c|c|c|c|}
\hline \multirow{2}{*}{ Indices } & \multicolumn{7}{|c|}{ Experimental group ${ }^{1}$} \\
\hline & $\mathrm{FB}_{0}$ & $\mathrm{HT}_{10}$ & $\mathrm{HT}_{20}$ & $\mathrm{HT}_{30}$ & $\mathrm{LT}_{10}$ & $\mathrm{LT}_{20}$ & $\mathrm{LT}_{30}$ \\
\hline \multicolumn{8}{|l|}{ Ingredients } \\
\hline wheat & 71.95 & 64.58 & 57.17 & 49.80 & 64.82 & 57.66 & 50.53 \\
\hline $\begin{array}{c}\text { soyabean meal } \\
(48.3 \% \mathrm{CP})\end{array}$ & 14.36 & 10.99 & 7.62 & 4.24 & 10.76 & 7.17 & 3.57 \\
\hline faba bean seeds & - & 10.0 & 20.0 & 30.0 & 10.0 & 20.0 & 30.0 \\
\hline $\begin{array}{l}\text { rape seeds } \\
\quad(20.7 \% \mathrm{CP})\end{array}$ & 8.00 & 8.00 & 8.00 & 8.00 & 8.00 & 8.00 & 8.00 \\
\hline lard & 2.77 & 3.54 & 4.31 & 5.08 & 3.50 & 4.24 & 4.98 \\
\hline $\begin{array}{l}\text { sodium bicar- } \\
\text { bonate }\end{array}$ & 0.10 & 0.10 & 0.10 & 0.10 & 0.10 & 0.10 & 0.10 \\
\hline sodium chloride & 0.22 & 0.22 & 0.22 & 0.22 & 0.22 & 0.22 & 0.22 \\
\hline limestone & 1.10 & 1.10 & 1.11 & 1.11 & 1.11 & 1.11 & 1.11 \\
\hline $\begin{array}{l}\text { monocalcium } \\
\text { phosphate }\end{array}$ & 0.52 & 0.53 & 0.55 & 0.56 & 0.53 & 0.55 & 0.56 \\
\hline choline chloride & 0.07 & 0.07 & 0.07 & 0.07 & 0.07 & 0.07 & 0.07 \\
\hline DL-methionine ${ }^{2}$ & 0.11 & 0.14 & 0.17 & 0.20 & 0.14 & 0.18 & 0.21 \\
\hline L-lysine $\mathrm{HCL}^{3}$ & 0.39 & 0.33 & 0.28 & 0.22 & 0.34 & 0.29 & 0.24 \\
\hline L-threonine $^{3}$ & 0.06 & 0.05 & 0.05 & 0.05 & 0.06 & 0.06 & 0.06 \\
\hline $\begin{array}{l}\text { vitamin-mineral } \\
\text { premix }\end{array}$ & 0.25 & 0.25 & 0.25 & 0.25 & 0.25 & 0.25 & 0.25 \\
\hline \multicolumn{8}{|l|}{ Analysed nutrients } \\
\hline crude fat & 7.58 & 8.02 & 8.36 & 8.62 & 7.55 & 7.88 & 8.22 \\
\hline \multicolumn{8}{|l|}{ Calculated nutrients ${ }^{5}$} \\
\hline $\begin{array}{l}\text { metabolizable } \\
\quad \text { energy, } \mathrm{kcal} \cdot \mathrm{kg}^{-1}\end{array}$ & 3150 & 3150 & 3150 & 3150 & 3150 & 3150 & 3150 \\
\hline crude fibre & 3.18 & 3.56 & 3.94 & 4.32 & 3.56 & 3.95 & 4.33 \\
\hline lysine & 1.05 & 1.05 & 1.05 & 1.05 & 1.05 & 1.05 & 1.05 \\
\hline $\begin{array}{l}\text { methionine + } \\
\text { cysteine }\end{array}$ & 0.73 & 0.73 & 0.73 & 0.73 & 0.73 & 0.73 & 0.73 \\
\hline threonine & 0.65 & 0.65 & 0.65 & 0.65 & 0.65 & 0.65 & 0.65 \\
\hline calcium & 0.65 & 0.65 & 0.65 & 0.65 & 0.65 & 0.65 & 0.65 \\
\hline $\begin{array}{l}\text { available phos- } \\
\text { phorus }\end{array}$ & 0.30 & 0.30 & 0.30 & 0.30 & 0.30 & 0.30 & 0.30 \\
\hline sodium & 0.13 & 0.13 & 0.13 & 0.13 & 0.13 & 0.13 & 0.13 \\
\hline
\end{tabular}

${ }^{1}$ diets in groups $\mathrm{FB}_{0}, \mathrm{HT}_{10}, \mathrm{HT}_{20}, \mathrm{HT}_{30}, \mathrm{LT}_{10}, \mathrm{LT}_{20}, \mathrm{LT}_{30}$ contained 0 , $10,20,30 \%$ of high-tannin (HT) or low-tannin (LT) faba bean seeds, respectively; ${ }^{2} 990 \mathrm{~g}$ methionine $\cdot \mathrm{kg}^{-1}$ (MetAMINO ${ }^{\circledR}$, Evonik Degussa Gmbh, Essen, Germany); ${ }^{3} 780 \mathrm{~g}$ lysine $\cdot \mathrm{kg}^{-1}, 985 \mathrm{~g}$ threonine $\cdot \mathrm{kg}^{-1}$ (Ajinomoto Eurolysine S.A.S, Amiens, France); ${ }^{4}$ provided per $\mathrm{kg}$ of feed (feeding period from 13 to 18 week): $\mathrm{mg}$ : retinol 2.52, cholecalciferol 0.09, a-tocopheryl acetate 70, vitamin $\mathrm{K}_{3} 4.2$, thiamine 3.5, riboflavin 5.6 , pyridoxine 4.2 , cobalamin 0.021 , biotin 0.21 , pantothenic acid 18, nicotinic acid 56, folic acid 2.1, Fe 42, Mn 84, Zn 77, Cu 14, I 2.1, Se 0.21, choline chloride $280 ;{ }^{5}$ calculation based on the analysed chemical composition of soyabean meal and faba bean seeds, and data from the Recommended Allowances and Nutritive Value of Feedstuffs. Poultry Feeding Standards for other compounds (Smulikowska and Rutkowski, 2005)

After 6 weeks of feeding, at 126 day of age, 7 turkeys per group (representing an average BW in each pen) were sacrificed by cervical dislocation. Digestive tract segments (small intestines and caeca) together with the contents were carefully collected and weighed. As soon as possible (approx. $20 \mathrm{~min}$ ), the $\mathrm{pH}$ of the ileal and caecal digesta was measured (mean of 3 readings) directly in the intestinal segment using a microelectrode and a $\mathrm{pH} / \mathrm{ION}$ metre (model 301, Hanna Instruments, Vila do Conde, Portugal). The small intestines and caeca (after digesta sampling) were flushed with water, blotted on filter paper and weighed as tissue mass. Fresh samples of ileal (middle 1/3 section of the ileum) and caecal contents were used for immediate analysis (ammonia, DM, viscosity). The remaining portion of the ileal and caecal digesta, including $0.4 \mathrm{~g}$ for the determination of microbiota enzyme activity and $0.2 \mathrm{~g}$ for the determination of short-chain fatty acid (SCFA) concentrations, was transferred to test tubes and stored at $-70{ }^{\circ} \mathrm{C}$ until further analyses.

\section{Analytical methods}

For chemical analyses, representative samples of seeds and diets were ground to pass through a $0.5 \mathrm{~mm}$ sieve. FB seeds were analysed in duplicate for $\mathrm{DM}$, crude protein $(\mathrm{CP} ; \mathrm{N} \times 6.25)$, crude fat (CF) and neutral detergent fibre (NDF) according to AOAC International (2005) methods 934.01, $976.05,920.39$ and 2002.4, respectively. Nonstarch polysaccharides (NSPs) and oligosaccharides (RFOs) were estimated by gas-liquid chromatography as described by Englyst and Cummings (1988) with modifications by Slominski et al. (2006). Total dietary fibre was determined by a combination of NDF and neutral detergent (ND)-soluble NSPs measurements, and was calculated as the sum of NDF and ND-soluble NSP. ND-soluble NSPs were calculated as total sample NSP minus NSP present in the NDF residue. ND-insoluble CP (NDICP) represented the amount of $\mathrm{CP}$ in the NDF residue. The contents of lignin and associated polyphenols were calculated as the difference [aNDF - (NSP + NDICP)]. Starch was analysed using the Megazyme Total Starch Kit (Megazyme International Ireland Ltd., Co. Wicklow, Ireland) according to 996.11 procedure of AOAC International (2005). Condensed tannins were estimated using acidified vanillin reagent (Broadhurst and Jones, 1978), and the results were expressed as catechin equivalents (CE). The ileal and caecal digesta were analysed for DM and ammonia. The DM of caecal digesta was determined at $105^{\circ} \mathrm{C}$. Ammonia extracted from fresh caecal digesta was trapped in a solution of boric acid in Conway's dishes and determined by direct titration with sulphuric acid. For digesta viscosity measurements, the content of the ileum was collected, mixed on a vortex mixer, and centrifuged at $7211 \mathrm{~g}$ for $10 \mathrm{~min}$ at $21^{\circ} \mathrm{C}$. 
The supernatant $(0.5 \mathrm{ml})$ was placed in a Brookfield LVDV-II cone-plate rotational viscometre (CP40; Brookfield Engineering Laboratories Inc., Stoughton, MA, USA), and the viscosity was measured at a fixed temperature of $39^{\circ} \mathrm{C}$ and at a shear rate of 60 per min. Viscosity values were recorded as apparent viscosity.

Bacterial extracellular enzymatic activity in deep-frozen stored caecal digesta was measured by the rate of $p$ - or $o$-nitrophenol release from their respective nitrophenylglucosides, according to the method described by Zduńczyk et al. (2010). Caecal SCFA concentrations were analysed by gas chromatography (Shimadzu GC-2010, Kyoto, Japan) on a capillary column (SGE BP21, $30 \mathrm{~m} \times$ $0.53 \mathrm{~mm}$, SGE Europe Ltd., Kiln Farm Milton Keynes, UK), as previously described (Zduńczyk et al., 2010).

\section{Statistical analysis}

The experiments were performed in a completely randomized design, and data was analysed using the GLM procedure of STATISTICA software (version 12; StatSoft Inc., 2014). According to growth performance parameters, each replicate pen $(n=7)$ was considered as an experimental unit. For the analysis of gastrointestinal parameters (microbial enzymatic activities and SCFA concentrations), individual birds $(n=7)$ were considered as experimental units. Control diet $\mathrm{FB}_{0}$ vs all HT diets or all LT diets were compared by planned contrast analysis. In a model without control group $\mathrm{FB}_{0}$, performance data were subjected to two-way ANCOVA with initial $\mathrm{BW}$ as the dependent variable. The remaining data were subjected to two-way ANOVA to examine the following effects: 1 . main effect of FB varieties (HT vs LT; V effect), 2. main effect of FB inclusion level (10, 20 and 30\%; L effect) and 3. interaction between $\mathrm{FB}$ varieties and inclusion level $(\mathrm{V} \times \mathrm{L})$. When a significant interaction effect was noted, the Newman-Keuls test was used to determine the differences between the factors. Data variability was expressed as a pooled standard error of the mean (SEM), and $P<0.05$ was considered statistically significant.

\section{Results}

\section{Chemical composition of faba bean seeds}

In comparison with HT seeds, in LT seeds the contents of CP (28.0 vs $29.3 \%$ ), total fibre (18.6 vs $19.7 \%$ ) and oligosaccharides (1.50 vs $1.90 \%)$ were slightly higher but the content of starch (44.4 vs $41.7 \%$ ) on a DM basis was lower (Table 2). Condensed tannin content was nearly 10 -fold higher in the HT variety than in the LT variety $(0.78$ vs $0.08 \%$ DM).

Table 2. Chemical composition of faba bean seeds with high and low tannin content, var. Bobas (HT) and Amulet (LT), respectively

\begin{tabular}{lcccc}
\hline \multirow{2}{*}{ Component } & \multicolumn{3}{c}{ Bobas - HT } & \multicolumn{2}{c}{ Amulet - LT } \\
& $\%$ as-is & $\%$ DM & $\%$ as-is & $\%$ DM \\
\hline Dry matter & 90.2 & & 89.0 & \\
Crude protein & 25.3 & 28.0 & 26.0 & 29.3 \\
Fat & 1.30 & 1.44 & 1.04 & 1.17 \\
Total dietary fibre & 16.8 & 18.6 & 17.5 & 19.7 \\
$\quad$ glycoproteins & 0.57 & 0.63 & 0.59 & 0.66 \\
$\quad$ lignin and polyphenols & 2.54 & 2.82 & 3.06 & 3.44 \\
$\quad$ non-starch polysaccharides & 13.6 & 15.1 & 13.9 & 15.6 \\
Starch $_{\text {Oligosaccharides }}{ }^{1}$ & 40.0 & 44.4 & 37.1 & 41.7 \\
Condensed tannins $^{2}$ & 1.35 & 1.50 & 1.69 & 1.90 \\
\hline
\end{tabular}

${ }^{1}$ including raffinose and stachyose; ${ }^{2}$ expressed as catechin equivalents

\section{Gastrointestinal function}

Differences in the diet composition exerted an insignificant effect on the analysed parameters of gastrointestinal tract functioning in turkeys (Table 3). The planned contrast analysis showed significant decrease in relative weight of small intestine with digesta after dietary application of LT seeds in comparison with the $\mathrm{FB}_{0}$ turkeys. The significant $\mathrm{V} \times \mathrm{L}$ interaction revealed higher relative weight of small intestine with digesta in turkeys fed diets $\mathrm{HT}_{10}$ vs all other treatments with FB.

In comparison with the control group $\mathrm{FB}_{0}$, diets containing HT enhanced the mucosal activity of sucrase and maltase in the small intestine $(P<0.05$; planned contrast analysis), which was not observed in turkeys fed LT diets. Two-way ANOVA showed significant $\mathrm{V} \times \mathrm{L}$ interaction between the values of small intestinal mucosal sucrase and maltase activities. The highest inclusion level of LT increased sucrase activity in comparison with the $\mathrm{LT}_{10}$ birds. Such effect was not observed between the HT groups. The $\mathrm{V} \times \mathrm{L}$ interaction of maltase activity was found when the lowest FB level (10\%) was added to the diet; the HT group significantly exceeded the $\mathrm{LT}_{10}$ birds. Two-way ANOVA showed that the LT treatment significantly increased the caecal digesta bulk vs the HT treatment $(P=0.012)$. The highest concentration of caecal ammonia was observed in the $\mathrm{LT}_{20}$ and $\mathrm{LT}_{30}$ groups $(P<0.05$ vs all other groups fed diets with FB; $P<0.008$ for $\mathrm{V} \times \mathrm{L}$ interaction). 
Table 3. Small intestinal and caecal parameters of turkeys

\begin{tabular}{|c|c|c|c|c|c|c|c|c|c|c|c|c|}
\hline \multirow{3}{*}{ Indices } & \multicolumn{7}{|c|}{ Small intestine } & \multicolumn{5}{|l|}{ Caeca } \\
\hline & \multirow{2}{*}{\multicolumn{2}{|c|}{$\begin{array}{l}\text { tissue with digesta } \\
\text { weight, } \mathrm{g} \cdot \mathrm{kg}^{-1} \mathrm{BW}\end{array}$}} & \multirow{2}{*}{$\begin{array}{l}\text { digesta } \\
\text { DM, \% }\end{array}$} & \multirow{2}{*}{$\begin{array}{l}\text { viscosity, } \\
\mathrm{mPa} \cdot \mathrm{s}\end{array}$} & \multicolumn{2}{|c|}{ sucrase maltase } & \multirow{2}{*}{$\begin{array}{l}\text { digesta } \\
\mathrm{pH}\end{array}$} & $\begin{array}{l}\text { tissue } \\
\text { weight }\end{array}$ & $\begin{array}{l}\text { digesta } \\
\text { weight }\end{array}$ & \multirow{2}{*}{$\begin{array}{l}\text { ammonia, } \\
\mathrm{mg} \cdot \mathrm{g}^{-1}\end{array}$} & \multicolumn{2}{|l|}{ digesta } \\
\hline & & & & & \multicolumn{2}{|c|}{$\overline{\mu \mathrm{mol} \cdot \mathrm{min}^{-1} \cdot \mathrm{g}^{-1} \text { protein }}$} & & \multicolumn{2}{|c|}{$\mathrm{g} \cdot \mathrm{kg}^{-1} \mathrm{BW}$} & & DM, \% & $\mathrm{pH}$ \\
\hline \multicolumn{13}{|c|}{ Treatments $^{1}$} \\
\hline $\mathrm{FB}_{0}$ & & 16.7 & 18.9 & 2.32 & 6.44 & 79.8 & 6.44 & 2.31 & 1.54 & 0.302 & 14.6 & 6.15 \\
\hline $\mathrm{HT}_{10}$ & & $18.9^{\mathrm{a}}$ & 21.0 & 2.31 & $9.71^{\mathrm{a}}$ & $120.9^{a}$ & 5.95 & 2.22 & 1.60 & $0.334^{b}$ & 15.2 & 6.32 \\
\hline $\mathrm{HT}_{20}$ & & $16.2^{\mathrm{b}}$ & 20.3 & 2.10 & $8.03^{a b}$ & $104^{a b}$ & 5.96 & 2.40 & 1.52 & $0.345^{b}$ & 15.4 & 6.22 \\
\hline $\mathrm{HT}_{30}$ & & $14.1^{\mathrm{b}}$ & 19.1 & 2.29 & $8.14^{a b}$ & $83.9^{a b}$ & 6.45 & 1.98 & 1.54 & $0.329^{b}$ & 16.2 & 6.09 \\
\hline $\mathrm{LT}_{10}$ & & $14.8^{\mathrm{b}}$ & 18.9 & 2.32 & $5.66^{b}$ & $73.6^{\mathrm{b}}$ & 6.29 & 2.17 & 2.18 & $0.484^{b}$ & 13.7 & 6.04 \\
\hline $\mathrm{LT}_{20}$ & & $14.6^{b}$ & 18.8 & 2.22 & $6.67^{\mathrm{ab}}$ & $94.0^{\mathrm{ab}}$ & 6.32 & 2.10 & 1.96 & $0.796^{a}$ & 15.3 & 5.89 \\
\hline $\mathrm{LT}_{30}$ & & $14.7^{\mathrm{b}}$ & 20.4 & 2.16 & $8.97^{\mathrm{a}}$ & $108.7^{\mathrm{ab}}$ & 6.22 & 2.09 & 1.80 & $0.803^{a}$ & 16.5 & 5.62 \\
\hline SEM & & 0.360 & 0.317 & 0.069 & 0.328 & 3.880 & 0.079 & 0.039 & 0.080 & 0.035 & 0.318 & 0.064 \\
\hline \multicolumn{13}{|c|}{ Significance level } \\
\hline $\mathrm{FB}_{0} \mathrm{vs}$ & & NS & NS & NS & 0.015 & 0.030 & NS & NS & NS & NS & NS & NS \\
\hline $\mathrm{FB}_{0} \mathrm{vs}$ & & 0.037 & NS & NS & NS & NS & NS & NS & NS & 0.001 & NS & 0.069 \\
\hline variet & & 0.016 & NS & NS & 0.025 & NS & NS & NS & 0.012 & 0.001 & NS & 0.008 \\
\hline inclus & evel (L) & 0.016 & NS & NS & NS & NS & NS & NS & NS & 0.007 & NS & NS \\
\hline$V \times L$ & raction & 0.023 & NS & NS & 0.015 & 0.002 & NS & NS & NS & 0.008 & NS & NS \\
\hline
\end{tabular}

${ }^{1}$ see Table 1; BW - body weight; DM - dry matter; SEM - pooled standard error of the mean; ${ }^{\text {ab }}$ - means within the same column with different superscripts are significantly different at $P<0.05 ;$ NS - not significant

The planned contrast analysis showed a trend to decrease caecal $\mathrm{pH}$ values in turkeys fed diets with LT seeds in comparison with the control ones $(P=0.069)$. Two-way ANOVA analysis revealed significant drop in caecal $\mathrm{pH}$ values upon diet LT vs HT $(P=0.008)$.

The dietary treatments significantly affected the bacterial extracellular activities of enzymes in caecal digesta (Table 4). The activity of bacterial $\alpha$-glucosidase was higher in HT than in LT groups $\left(P=0.011\right.$; two-way ANOVA) and control group $\mathrm{FB}_{0}$ $(P=0.047$; planned contrast analysis). According to $\mathrm{V} \times \mathrm{L}$ interaction, in $\mathrm{LT}$ groups $\beta$-glucosidase activity significantly increased in line with the increasing FB level; such interaction was not found in HT groups. Also, $\mathrm{V} \times \mathrm{L}$ interaction indicates that $\alpha$-galactosidase, $\beta$-galactosidase and $\beta$-xylosidase activities in the groups fed LT were different among the highest and the lowest $\mathrm{FB}$ addition $\left(\mathrm{LT}_{10}>\mathrm{LT}_{30}\right)$; such differences were not found in the HT birds. The planned contrast analysis showed that irrespective of FB type and level, significantly lower $\beta$-glucuronidase activity in the caecal digesta in $\mathrm{FB}_{0}$ birds $(P<0.05$ vs all HT and LT groups) was found.

Table 4. Activity of selected microbial glycolytic enzymes in the caecal digesta of turkeys

\begin{tabular}{|c|c|c|c|c|c|c|c|}
\hline \multirow{2}{*}{ Indices } & \multicolumn{7}{|c|}{ Activity, $\mu \mathrm{mol} \cdot \mathrm{h}^{-1} \cdot \mathrm{g}^{-1}$} \\
\hline & a-glucosidase & $\beta$-glucosidase & a-galactosidase & $\beta$-galactosidase & $\beta$-glucuronidase & a-arabinopyranosidase & $\beta$-xylosidase \\
\hline \multicolumn{8}{|l|}{ Treatments $^{1}$} \\
\hline $\mathrm{FB}_{0}$ & 18.2 & 1.56 & 118 & 251 & 4.10 & 5.49 & 14.6 \\
\hline $\mathrm{HT}_{10}$ & 23.8 & $2.97^{\mathrm{abc}}$ & $11 g^{a b}$ & $246^{\mathrm{ab}}$ & 12.3 & 7.43 & $14.5^{\mathrm{b}}$ \\
\hline $\mathrm{HT}_{20}$ & 23.1 & $3.44^{\mathrm{ab}}$ & $150^{\mathrm{a}}$ & $313^{a b}$ & 15.9 & 6.82 & $18.2^{\mathrm{ab}}$ \\
\hline $\mathrm{HT}_{30}$ & 23.6 & $1.49^{b c}$ & $143^{a}$ & $360^{\mathrm{ab}}$ & 14.0 & 6.52 & $18.9^{a b}$ \\
\hline $\mathrm{LT}_{10}$ & 15.9 & $1.20^{\circ}$ & $200^{a}$ & $474^{a}$ & 13.7 & 11.0 & $26.5^{\mathrm{a}}$ \\
\hline $\mathrm{LT}_{20}$ & 15.7 & $2.57^{\mathrm{abc}}$ & $117^{a b}$ & $325^{\mathrm{ab}}$ & 13.5 & 7.85 & $23.4^{\mathrm{ab}}$ \\
\hline $\mathrm{LT}_{30}$ & 24.0 & $3.90^{\mathrm{a}}$ & $51.4^{\mathrm{b}}$ & $138^{b}$ & 19.4 & 5.00 & $13.2^{\mathrm{b}}$ \\
\hline SEM & 0.951 & 0.266 & 10.14 & 24.68 & 1.488 & 0.555 & 1.318 \\
\hline \multicolumn{8}{|l|}{ Significance level } \\
\hline $\mathrm{FB}_{0}$ vs HT & 0.047 & NS & NS & NS & 0.029 & NS & NS \\
\hline $\mathrm{FB}_{0}$ vs LT & NS & NS & NS & NS & 0.013 & NS & NS \\
\hline variety $(\mathrm{V})$ & 0.011 & NS & NS & NS & NS & NS & NS \\
\hline inclusion level $(L)$ & NS & NS & 0.039 & NS & NS & NS & NS \\
\hline$V \times L$ interaction & NS & 0.007 & 0.003 & 0.001 & NS & NS & 0.031 \\
\hline
\end{tabular}

${ }^{1}$ see Table 1; SEM - pooled standard error of the mean; abc - means within the same column with different superscripts are significantly different at $P<0.05$; NS - not significant 
Table 5. Concentrations and profile of short-chain fatty acids (SCFAs) in the caecal digesta

\begin{tabular}{|c|c|c|c|c|c|}
\hline \multirow[t]{2}{*}{ Indices } & \multirow{2}{*}{$\begin{array}{l}\text { Total SCFA } \\
\text { concentration, } \\
\mu \mathrm{mol} \cdot \mathrm{g}^{-1}\end{array}$} & \multirow{2}{*}{$\begin{array}{l}\text { SCFA pool, } \\
\mu \mathrm{mol} \cdot \mathrm{kg}^{-1} \\
\mathrm{BW}\end{array}$} & \multicolumn{3}{|c|}{$\begin{array}{l}\text { SCFA profile, } \\
\% \text { of } \Sigma \text { SCFAs }\end{array}$} \\
\hline & & & $\mathrm{C} 2$ & $\mathrm{C} 3$ & $\mathrm{C} 4$ \\
\hline \multicolumn{6}{|l|}{ Treatments $^{1}$} \\
\hline $\mathrm{FB}_{0}$ & 187 & 288 & 61.2 & 10.7 & 24.9 \\
\hline $\mathrm{HT}_{10}$ & 163 & 265 & 65.8 & $10.5^{a b}$ & 20.3 \\
\hline $\mathrm{HT}_{20}$ & 160 & 244 & 64.4 & $9.74^{\mathrm{ab}}$ & 22.7 \\
\hline $\mathrm{HT}_{30}$ & 155 & 242 & 62.7 & $12.2^{\mathrm{a}}$ & 22.5 \\
\hline $\mathrm{LT}_{10}$ & 185 & 411 & 63.4 & $11.8^{\mathrm{a}}$ & 21.5 \\
\hline $\mathrm{LT}_{20}$ & 224 & 443 & 61.6 & $10.1^{\mathrm{ab}}$ & 25.4 \\
\hline $\mathrm{LT}_{30}$ & 230 & 411 & 61.6 & $7.48^{\mathrm{b}}$ & 28.4 \\
\hline SEM & 5.64 & 20.95 & 0.460 & 0.378 & 0.529 \\
\hline \multicolumn{6}{|l|}{ Significance level } \\
\hline $\mathrm{FB}_{0}$ vs HT & 0.040 & NS & 0.024 & NS & 0.018 \\
\hline $\mathrm{FB}_{0}$ vs LT & 0.050 & 0.022 & NS & NS & NS \\
\hline variety (V) & 0.001 & 0.001 & 0.038 & NS & 0.001 \\
\hline inclusion level (L) & ) NS & NS & NS & NS & 0.001 \\
\hline$V \times L$ interaction & NS & NS & NS & 0.005 & 0.103 \\
\hline
\end{tabular}

${ }^{1}$ see Table 1; SEM - pooled standard error of the mean; BW - body weight; C2 - acetic acid; C3 - propionic acid; C4 - butyric acid; ab - means within the same column with different superscripts are significantly different at $P<0.05$; NS - not significant

Dietary treatments with FB affected the production of SCFAs in the caecal digesta (Table 5). Total caecal SCFA concentration and pool were significantly higher in turkeys fed diets with LT than with HT seeds (both $P=0.001$, two-way ANOVA analysis). The planned contrast analysis revealed that dietary HT seeds significantly decreased while LT seeds significantly increased total SCFA concentration in the caecal digesta in comparison with the control $\mathrm{FB}_{0}$ birds. Additionally, the LT diet, but not the HT one, caused a significant enhancement in caecal SCFA pool vs group $\mathrm{FB}_{0}$. In comparison with group $\mathrm{FB}_{0}$, dietary HT seeds contributed to a higher percentage of acetate $(\mathrm{C} 2)$ and a lower percentage of butyrate $(\mathrm{C} 4)$ in the SCFA profile $(P=0.024$ and 0.018 , respectively; planned contrast analysis). According two-way ANOVA analysis, SCFA profile, dietary LT seeds treatment enhanced $\mathrm{C} 4$ percentage at the expanse of $\mathrm{C} 2$ as compared with HT seeds. Additionally, a significant increase in the $\mathrm{C} 4$ proportion followed increased level of FB dietary inclusion. The higher proportion of propionic acid (C3) in the caecal SCFA profile in the birds fed $\mathrm{HT}_{30}$ and $\mathrm{LT}_{10}$ diets in comparison with the turkeys fed $\mathrm{LT}_{30}$ diet was found according to significant $\mathrm{V} \times \mathrm{L}$ interaction.

\section{Growth performance}

Between 13 and 18 week, FB variety and inclusion level had no influence on feed intake (Table 6). The BWGs of turkeys were comparable in all groups,
Table 6. Performance of turkeys from 13 to 18 week of age

\begin{tabular}{|c|c|c|c|c|}
\hline Indices & $\begin{array}{l}\text { Daily feed } \\
\text { intake, } \\
\mathrm{kg} \cdot \text { bird }^{-1}\end{array}$ & $\begin{array}{l}\text { Body weight } \\
\text { gain, } \\
\mathrm{kg} \cdot \text { bird }^{-1}\end{array}$ & $\begin{array}{l}\text { Feed } \\
\text { conversion } \\
\text { ratio, } \mathrm{kg} \cdot \mathrm{kg}^{-1}\end{array}$ & $\begin{array}{l}\text { Mortality, } \\
\text { bird } / \%\end{array}$ \\
\hline \multicolumn{5}{|l|}{ Treatments $^{1}$} \\
\hline $\mathrm{FB}_{0}$ & 0.600 & 8.33 & 3.03 & $1 / 0.47$ \\
\hline $\mathrm{HT}_{10}$ & 0.619 & 8.37 & 3.08 & $0 / 0.0$ \\
\hline $\mathrm{HT}_{20}$ & 0.609 & 8.29 & 3.04 & $1 / 0.47$ \\
\hline $\mathrm{HT}_{30}$ & 0.610 & 8.29 & 3.06 & $1 / 0.47$ \\
\hline $\mathrm{LT}_{10}$ & 0.606 & 8.38 & 2.99 & $1 / 0.47$ \\
\hline $\mathrm{LT}_{20}$ & 0.610 & 8.39 & 3.00 & $0 / 0.0$ \\
\hline $\mathrm{LT}_{30}$ & 0.607 & 8.39 & 3.00 & $1 / 0.47$ \\
\hline SEM & 0.003 & 0.250 & 0.011 & ND \\
\hline \multicolumn{5}{|l|}{ Significance level } \\
\hline $\mathrm{FB}_{0}$ vs HT & NS & NS & NS & ND \\
\hline $\mathrm{FB}_{0}$ vs LT & NS & NS & NS & ND \\
\hline variety (V) & NS & NS & 0.014 & ND \\
\hline inclusion level $(\mathrm{L})$ & NS & NS & NS & ND \\
\hline$V \times L$ interaction & NS & NS & NS & ND \\
\hline
\end{tabular}

and FCR values were lower in birds fed LT than HT $\operatorname{diet}$ (two-way ANOVA, variety effect $P=0.014$ ). The mortality rate was $0.47 \%$ per group (except groups $\mathrm{HT}_{10}$ and $\mathrm{LT}_{20}$ without dead birds).

\section{Discussion}

In the present study, the content of $\mathrm{CP}$, fibre fractions and starch in FB seeds was similar with the values reported by other authors (Zijlstra et al., 2008; Nalle et al., 2010) who used seeds of other FB varieties grown in other soil and climatic conditions. Previous researches (Frejnagel et al., 1997; Zduńczyk et al., 2003) have shown that the most popular Polish FB variety, Nadwiślański, contains more than $1 \%$ of polyphenols on a DM basis, including $0.8 \%$ of proanthocyjanidins, and that the low-tannin Caspar variety has lower content of these compounds ( 0.28 and $0.03 \%$, respectively). In our experiment, condensed tannin content was nearly 10-fold higher in the HT FB variety than in the LT variety $(0.78$ vs $0.08 \%$ $\mathrm{DM})$. Such difference is consistent with the classification of FB varieties grown in Poland, according to which Amulet is a low-tannin variety and Bobas is a high-tannin variety (COBORU, 2011). In our study the tannin content of LT FB $\left(<1 \mathrm{mg} \cdot \mathrm{g}^{-1} \mathrm{DM}\right)$ was similar to that reported by Hejdysz et al. (2016).

In the present experiment, in turkeys fed LT FB seeds the weights of small intestinal walls and digesta decreased. This is consistent with the findings of Nalle et al. (2010) who reported higher empty weight and digesta weight of gizzard in broilers fed diets 
containing FB than in birds fed maize-SBM-based diets. In contrast to the above findings, in our study the amount of small intestinal digesta was lower in turkeys fed diet with the highest content of HT FB than in birds fed diet with the lowest content of HT seeds. Such an effect can be explained by the results of previous experiments where the relative length of the small intestine and caeca decreased in chickens fed diets supplemented with polyphenol-rich extracts (Erener et al., 2011).

In our study, FB had no influence on the viscosity of small intestinal digesta. According to previous research (Jankowski et al., 2011), the viscosity of small intestinal digesta increases in animals fed diets with higher concentrations of raffinose family oligosaccharides (RFOs). The total oligosaccharide content of the FB seeds in our experiment was below $2 \%$, and a higher value $(2.05-2.36 \% \mathrm{DM})$ was reported by Frejnagel et al. (1997).

Previous research has demonstrated that a high content of FB tannins in chicken diets decreases the activities of endogenous enzymes in the digestive tract (Longstaff and McNab, 1991), including maltase and sucrase (Iji et al., 2004; Nyamambi et al., 2007). In our study, sucrase activity decreased in turkeys fed diets with the highest content of HT and LT FB seeds, whereas maltase activity decreased in birds fed diets with HT and the highest content of LT seeds. Such results may suggest that polyphenols exert a relatively insignificant influence on the activities of the analysed enzymes in the intestinal mucosa (noted at the highest dietary inclusion level of FB seeds), and that the activity of those enzymes is also affected by other components of FB seeds.

It has been reported that increased dietary polyphenol content reduces the enzymatic activity of large gut microbiota (Kosmala et al., 2011). An earlier study of HT and LT FB seeds added to rat diets (Zduńczyk et al., 2003) revealed no significant differences in the activities of $\alpha$-glucosidase, $\beta$-glucosidase, $\alpha$-galactosidase and $\beta$-galactosidase, but LT seeds significantly increased the activity of microbial $\beta$-glucuronidase. Longstaff and $\mathrm{McNab}$ (1991) also observed different effect of dietary tannin levels on enzyme activities in chicken gut microbiota. The cited authors found that diets with low tannin content may stimulate the activities of selected digestive enzymes, whereas diets with high tannin content can inhibit their activities. The results obtained in the present experiment showed that the dietary polyphenols level in the diet with HT seeds was not a factor that limits enzymatic activity of caecal microbiota. The lowest activity of some bacterial enzymes found in the LT groups may indicate that seed constituents other than polyphenols (e.g., lignins, oligosaccharides) may control (diminish) enzymatic activity of caecal microbiota.

In our study, increasing levels of FB seeds in turkey diets did not increase the total concentration or the pool of SCFAs in the caecal digesta because of the lower content of RFOs and higher contents of NDF and acid detergent fibre (ADF) in faba beans than in soyabeans (Jezierny et al., 2010). As a result, the amount of substrates used in fermentation processes (oligosaccharides and non-starch polysaccharides) may be similar in SBM-based and SBM-FB-based diets. In accordance with previous findings (Fotschki et al., 2014), we assumed that a decrease in the tannin content of FB seeds would limit the inhibitory effect of those compounds on the metabolic activity of gut microbiota. The substitution of LT for HT seeds led to an increase in the total concentration of SCFAs in the caecal digesta, but the total SCFA pool did not increase because the amount of digesta was smaller. This indicates that the amount of substrates used in fermentation processes was comparable due to the similar chemical composition of seeds of both FB varieties, which resulted in similar SCFA pools in the caecal digesta.

In our experiment, LT FB decreased the percentage of acetate and increased the percentage of butyrate in the total SCFA pool, in comparison with HT seeds. SCFAs are rapidly absorbed and metabolized by various tissues, including the liver (propionate and partially acetate) and muscles (acetate), and they are directly utilized by the intestinal epithelium (butyrate) (Priebe et al., 2002). For this reason, butyric acid is more effective in inducing the proliferation of intestinal epithelial cells than acetic acid, the main product of caecal fermentation in poultry (Zduńczyk et al., 2015). Thus, the increase in the proportion of butyrate in the total SCFA pool in turkeys fed LT FB can be considered highly desirable.

In the present study, partial replacement of SBM with FB, including HT seeds, had no adverse effect on the growth performance of turkeys. Previous research has revealed a negative effect of tannins on feed consumption and the growth rate of broiler chickens (Iji et al., 2004). According to some studies, the effect exerted by tannins may be related to the stage of development of the digestive tract, and therefore birds older than 8 weeks are able to tolerate dietary tannins (Douglas et al., 1993). Our findings show that in the final stage of fattening, turkeys can be fed diets containing both LT and HT FB. The results of this study corroborate the findings 
of Helsper et al. (1996) who demonstrated higher FCR values in broiler chickens fed diets with tannincontaining FB than in those receiving diets with corresponding level of tannin-free FB.

\section{Conclusions}

Faba bean (FB) seeds enhanced fermentation processes in the gastrointestinal tract of finisher turkeys, but had no influence on their growth performance. Both low- and high-tannin FB seeds $(0.08$ and $0.78 \%$ of tannins, respectively) can be included in finisher turkey diets at up to $30 \%$ as substitute for soyabean meal. Furthermore, a decrease in the tannin content of FB improved selected parameters of intestinal function, including more desirable short chain fatty acid (SCFA) profile and increased production of SCFAs in the caeca of turkeys, which could improve feed efficiency.

\section{Acknowledgements}

This study was carried out within research project No 505.037.07 'Improvement of native plant protein feeds, their production, trade turnover and utilization in animal feed mixtures', funded by the Polish Ministry of Agriculture and Rural Development.

\section{References}

AOAC International, 2005. Official Methods of Analysis of the AOAC International. 18 $8^{\text {th }}$ Edition. Gaithersburg, MD (USA)

Broadhurst R.B., Jones W.T., 1978. Analysis of condensed tannins using acidified vanillin. J. Sci. Food Agric. 29, 788-794, https:// doi.org/10.1002/jsfa.2740290908

Cazzato E., Tufarelli V., Ceci E., Stellacci A.M., Laudadio V., 2012. Quality, yield and nitrogen fixation of faba bean seeds as affected by sulphur fertilization. Acta Agric. Scand. Sect. B - Soil Plant Sci. 62, 732-738, https://doi.org/10.1080/09064710.2012.698642

COBORU, 2011. Descriptive Register of Varieties. Part 2 (in Polish). Słupia Wielka (Poland)

Douglas J.H., Sullivan T.W., Gonzalez N.J., Beck M.M., 1993. Differential age response of turkeys to protein and sorghum tannin levels. Poult. Sci. 72, 1944-1951, https://doi.org/10.3382/ps.0721944

Duc G., Marget P., Esnault R., Le Guen J., Bastianelli D., 1999. Genetic variability for feeding value of faba bean seeds (Vicia faba): comparative chemical composition of isogenics involving zero-tannin and zero-vicine genes. J. Agric. Sci. 133, 185-196, https://doi.org/10.1017/S0021859699006905

Englyst H.N., Cummings J.H., 1988. Improved method for determination of dietary fiber as non-starch polysaccharides in plant foods. J. Assoc. Off. Anal. Chem. 71, 808-814

Erener G., Ocak N., Altop A., Cankaya S., Aksoy H.M., Ozturk E., 2011. Growth performance, meat quality and caecal coliform bacteria count of broiler chicks fed diet with green tea extract. Asian Australas. J. Anim. Sci. 24, 1128-1135, https://doi. org/10.5713/ajas.2011.10434
Fotschki B., Milala J., Jurgoński A., Karlińska E., Zduńczyk Z., Juśkiewicz J., 2014. Strawberry ellagitannins thwarted the positive effects of dietary fructooligosaccharides in rat cecum. J. Agric. Food Chem. 62, 5871-5880, https://doi.org/10.1021/ jf405612a

Frejnagel S., Zduńczyk Z., Krefft B., 1997. The chemical composition and nutritive value of low- and high-tannin faba bean varieties. J. Anim. Feed Sci. 6, 401-412, https://doi.org/10.22358/ jafs/69536/1997

Hejdysz M., Kaczmarek S.A., Rutkowski A., 2016. Extrusion cooking improves the metabolisable energy of faba beans and the amino acid digestibility in broiler. Anim. Feed Sci. Technol. 212, 100-111, https://doi.org/10.1016/j.anifeedsci.2015.12.008

Helsper J.P.F.G., van Loon Y.P.J., Kwakke R.P., van Norel A., van der Poel A.F.B., 1996. Growth of broiler chicks fed diets containing tannin-free and tannin-containing near-isogenic lines of faba bean (Vicia faba L.). J. Agric. Food Chem. 44, 1070-1075, https://doi.org/10.1021/jf950484w

Hybrid Turkey, 2013. Commercial Nutrient Guidelines (accessed 10.08.16) http://www.resources.hybridturkeys.com/nutrition/ commercial-guidelines

lji P.A., Khumalo K., Slippers S., Gous R.M., 2004. Intestinal function and body growth of broiler chickens on maize-based diets supplemented with mimosa tannins and a microbial enzyme. J. Sci. Food Agric. 84, 1451-1458, https://doi.org/10.1002/ jsfa. 1816

Jankowski J., Lecewicz A., Zdunczyk Z., Juskiewicz J., Slominski B.A., 2011. The effect of partial replacement of soyabean meal with sunflower meal on ileal adaptation, nutrient utilisation and growth performance of young turkeys. Br. Poult. Sci. 52, 456-465, https://doi.org/10.1080/00071668.2011.602664

Jezierny D., Mosenthin R., Bauer E., 2010. The use of grain legumes as a protein source in pig nutrition: A review. Anim. Feed Sci. Technol. 157, 111-128, https://doi.org/10.1016/j.anifeedsci.2010.03.001

Kosmala M., Kołodziejczyk K., Zduńczyk Z., Juśkiewicz J., Boros D., 2011. Chemical composition of natural and polyphenol-free apple pomace and the effect of this dietary ingredient on intestinal fermentation and serum lipid parameters in rats. J. Agric. Food Chem. 59, 9177-9185, https://doi.org/10.1021/ jf201950y

Laudadio V., Ceci E., Tufarelli V., 2011. Productive traits and meat fatty acid profile of broiler chickens fed diets containing micronized fava beans (Vicia faba L. var. minor) as the main protein source. J. Appl. Poult. Res. 20, 12-20, https://doi. org/10.3382/japr.2010-00173

Longstaff M.A., McNab J.M., 1991. The effect of concentration of tannin-rich bean hulls (Vicia faba L.) on activities of lipase (EC 3.1.1.3) and a-amylase (EC 3.2.1.1.) in digesta and pancreas and on the digestion of lipid and starch by young chicks. $\mathrm{Br}$. J. Nutr. 66, 139-147, https://doi.org/10.1079/BJN19910017

Nalle C.L., Ravindran V., Ravindran G., 2010. Nutritional value of faba bean (Vicia faba L.) for broilers: Apparent metabolisable energy, ileal amino acid digestibility and production performance. Anim. Feed Sci. Technol. 156, 104-111, https://doi. org/10.1016/j.anifeedsci.2010.01.010

NRC, 1994. Nutrient Requirements of Poultry: $9^{\text {th }}$ Revised Edition. The National Academies Press.Washington, DC (USA), https:// doi.org/10.17226/2114

Nyamambi B., Ndlovu L.R., Naik Y.S., Kock N.D., 2007. Intestinal growth and function of broiler chicks fed sorghum based diets differing in condensed tannin levels. South Afr. J. Anim. Sci. 37, 202-214, https://doi.org/10.4314/sajas.v37i3.4092 
Priebe M.G., Vonk R.J., Sun X., He T., Harmsen H.J.M., Welling G.W., 2002. The physiology of colonic metabolism. Possibilities for interventions with pre- and probiotics. Eur. J. Nutr. 41, Suppl. 1 , i2-i10, https://doi.org/10.1007/s00394-002-1101-8

Slominski B.A., Meng X., Campbell L.D., Guenter W., Jones O., 2006. The use of enzyme technology for improved energy utilization from full-fat oilseeds. Part II: Flaxseed. Poult. Sci. 85, 1031-1037, https://doi.org/10.1093/ps/85.6.1031

Smulikowska S., Chibowska M., 1993. The effect of variety, supplementation with tryptophan, dehulling and autoclaving on utilization of field bean (Vicia faba L.) seeds by broiler chickens. J. Anim. Feed Sci. 2, 181-189, https://doi.org/10.22358/ jafs/69880/1993

Smulikowska S., Rutkowski A. (Editors), 2005. Recommended Allowances and Nutritive Value of Feedstuffs. Poultry Feeding Standards (in Polish). $4^{\text {th }}$ Edition. The Kielanowski Institute of Animal Physiology and Nutrition, Polish Academy of Sciences, Jabłonna (Poland)

StatSoft Inc., 2014. STATISTICA (data analysis software system), version 12, http://www.statsoft.com

Tufarelli V., Laudadio V., 2015. Feeding of dehulled-micronized faba bean (Vicia faba var. minor) as substitute for soybean meal in guinea fowl broilers: effect on productive performance and meat quality. Asian Australas. J. Anim. Sci. 28, 1471-1478, https://doi.org/10.5713/ajas.15.0245

Van Der Poel A.F.B., Dellaert L.M.W., Van Norel A., Helsper J.P.F.G., 1992. The digestibility in piglets of faba bean (Vicia faba L.) as affected by breeding towards the absence of condensed tannins. Br. J. Nutr. 68, 793-800, https://doi.org/10.1079/ BJN19920134
Vilariño M., Métayer J.P., Crépon K., Duc G., 2009. Effect of varying vicine, convicine and tannin contents of faba bean seeds (Vicia faba L.) on nutritional values for broiler chicken. Anim. Feed Sci. Technol. 150, 114-121, https://doi.org/10.1016/j.anifeedsci.2008.08.001

Zduńczyk Z., Jankowski J., Juśkiewicz J., Lecewicz A., Slominski B.A., 2010. Application of soybean meal, soy protein concentrate and isolate differing in a-galactosides content to low- and highfibre diets in growing turkeys. J. Anim. Physiol. Anim. Nutr. 94, 561-570, https://doi.org/10.1111/j.1439-0396.2009.00939.x

Zduńczyk Z., Jankowski J., Kaczmarek S., Juśkiewicz J., 2015. Determinants and effects of postileal fermentation in broilers and turkeys part 1: gut microbiota composition and its modulation by feed additives. Worlds Poult. Sci. J. 71, 37-47, https://doi. org/10.1017/S0043933915000045

Zduńczyk Z., Juśkiewicz J., Wróblewska M., Flis M., 2003. Effect of faba bean seeds with different content of proanthocyanidins on growth rate of rats, caecal enzyme activity and metabolism indices. Acta Aliment. 32, 161-168, https://doi.org/10.1556/ AAlim.32.2003.2.5

Zijlstra R.T., Lopetinsky K., Beltranena E., 2008. The nutritional value of zero-tannin faba bean for grower-finisher pigs. Can. J. Anim. Sci. 88, 293-302, https://doi.org/10.4141/CJAS07146 